\title{
Eurasia: Investing for the future
}

Written by: Andreas Schaal, Director, OECD Global Relations Secretariat

Last update: 22 June 2018

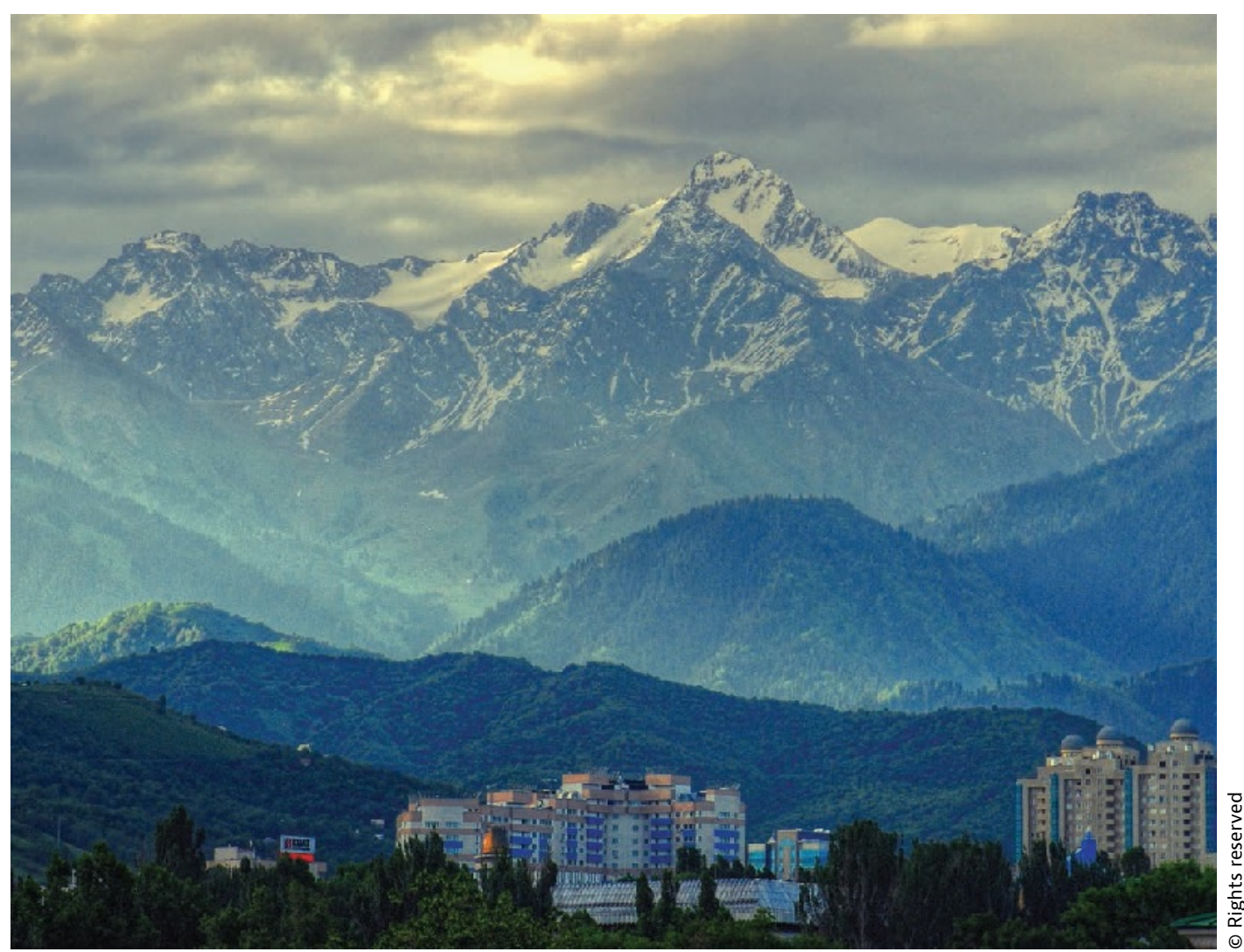

After an extended period of relatively strong economic growth, the countries of Eurasia* have recently experienced a series of powerful external economic shocks. Lower global commodity prices, recession in Russia, moderate growth in China and subdued economic prospects in many west European economies have all hit Eurasia hard. The region's overall GDP fell in 2015, for only the second time in two decades (the first time was in 2009), and growth in 2016 was weak, according to IMF estimates, with accelerations in a few countries offset by downturns elsewhere. Recovery seems to have continued into 2017 but is uneven and modest at best, and growth is far below the rates achieved in the 2000s. 
The region's oil and metals exporters have naturally been hit hardest by the end of the commodities boom, but, perhaps surprisingly, the comparatively resourcepoor economies of Eurasia* have also suffered. Many rely heavily on trade with, and remittances from oil exporters, particularly Russia. Moreover, the conflict in Ukraine, which has inflicted enormous costs on the country, has also affected the rest of Eurasia, mainly as a result of the impact of western sanctions and Russian counter-sanctions on trade flows, as well as the effect of heightened uncertainty on investment.

These developments have highlighted some of the structural vulnerabilities of the Eurasia economies. Most have a relatively concentrated export profileparticularly in terms of goods exported but also, in many cases, a heavy reliance on a few key export markets. In a number of Eurasia countries, hydrocarbons and metals account for $80-90 \%$ of exports, and the remaining exports depend heavily on agricultural goods with minimal or no processing. Moreover, the data suggest that for most Eurasia countries in the years preceding the present slowdown the commodity share of exports was increasing in many countries.

\section{The diversification imperative}

This problem is not new: the challenge of economic diversification has loomed large on the region's policy agenda for well over a decade, especially in the oilexporting economies. There was widespread awareness, even during the boom years before the global financial crisis in 2008 , that sustained long-term growth would require a transition to more investment-led and innovation-led growth. The slower rates that followed the crisis-even before the shocks of 2014-seemed to confirm that the growth models from the previous decade were reaching their limits. In fact, our calculations show that the aggregate GDP of the Eurasia region grew by more than $8.5 \%$ per year from 2000 to 2008 , but grew just $5.1 \%$ per year in the post-crisis recovery period from 2010 to 2013, before stalling in 2014 and 2015.

When thinking about diversification, policymakers often tend to think in terms of sectors. This poses a problem, largely because such a focus inhibits politicians and officials from identifying the most promising long-term trends in product markets. A more effective approach to diversification focuses on building up a country's endowments-its natural, human, physical and financial capital. At first glance, it might seem that countries can do little about their natural endowments but there is, in fact, a great deal that depends on policy. For example, while governments cannot change the quality or composition of the soil, the economic potential of such resources is influenced by legislative and regulatory factors, as well as physical infrastructure and technological capacities-hence the importance of Kazakhstan's current overhaul of its mining code or Ukraine's efforts to advance land reform. Similarly, reforms to water policy and water governance in Central Asian states like Tajikistan could support both economic growth and long-term environmental sustainability. 
The benefits of higher productivity and inclusive growth

But reducing external vulnerabilities requires more than diversifying productive activity or exports. Raising productivity also plays a critical role. If these countries are to make the most of their people's

the countries of Eurasia need to invest in human capital development talents and to allow the great mass of their citizens to pursue productive, rewarding careers, the countries of Eurasia need to invest in human capital development. This also means fostering activities that generate more highskilled and high-productivity employment which directly contributes to the economic well-being of the country and the social well-being of its people. At present, many of the Eurasia countries are characterised by wide disparities in productivity, income and, as a result, well-being, because high-productivity employment in many countries is concentrated in just a few sectors and regions. The case of Kazakhstan is instructive here: value added per worker in resource extraction is more than eight times the national average but it accounts for only about $2 \%$ of total employment. By contrast, our calculations based on official data suggest that around $28 \%$ of employment is in sectors where output per worker is only about $16 \%$ of the average. Higher productivity and inclusive growth require more focus on further reforms to education and training systems, which have in some cases changed little since communist times.

\section{Good governance for well-functioning markets}

Above all, though, the Eurasia countries need to continue to build up their institutional capital, strengthening public governance and the rule of law, while creating sound framework conditions for investment, entrepreneurship and innovation. Well-designed and well-functioning regulatory and tax regimes are critical, as well as secure property rights, fair competition and open markets.

The good news is that the region's governments are far from idle. The squeeze of the last two years has triggered a new round of reforms in such diverse fields as customs regulation, tax administration and investor protection. Support for startups is expanding. But there is more to be done, particularly to create favourable conditions for the growth of new firms and SMEs, the critical drivers of innovation, job creation and diversification.

The OECD continues to support countries in Eurasia in designing and implementing institutional and policy reforms that will help strengthen their economic endowments and set them on a path to sustainable, inclusive growth.

*"Eurasia" refers to the countries participating in the OECD Eurasia Competitiveness Programme: Afghanistan, Armenia, Azerbaijan, Belarus, Georgia, Kazakhstan, Kyrgyzstan, the Republic of Moldova, Mongolia, Tajikistan, Turkmenistan, Ukraine and Uzbekistan.

Share article at http://oe.cd/25Q 


\section{References}

IMF (2016), World Economic Outlook: Subdued Demand: Symptoms and Remedies, IMF, Washington, D.C. www.imf.org/external/pubs/ft/weo/ 2016/02/pdf/text.pdf

Agency for Statistics of the Republic of Kazakhstan http://www.stat.gov.kz

High-level representatives from Eurasia and OECD countries met in Almaty, Kazakhstan, on 23-25 October 2017 for the fourth annual OECD Eurasia Week, to exchange perspectives on "Openness for shared prosperity", assess progress made, and discuss the region's future reform agenda. To learn more about the OECD's work with the Eurasia region www.oecd.org/eurasia 